\title{
DUKUNGAN SOSIAL SEBAGAI MEDIATOR PENGARUH RASA SYUKUR TERHADAP KEPUASAN HIDUP GURU PADA SAAT PEMBELAJARAN DARING
}

\author{
Yulia Lestari Tarihoran ${ }^{1}$, Pamela Hendra Heng ${ }^{2}$, Sri Tiatri ${ }^{3}$ \\ ${ }^{1}$ Program Studi Magister Psikologi, Universitas Tarumanagara, Jakarta \\ Email: yulia.707191001@stu.untar.ac.id \\ ${ }^{2}$ Fakultas Psikologi, Universitas Tarumanagara, Jakarta \\ Email:pamelah@fpsi.untar.ac.id \\ ${ }^{3}$ Fakultas Psikologi, Universitas Tarumanagara, Jakarta \\ Email: sri.tiatri@untar.ac.id
}

Masuk : 12-06-2021, revisi: 26-09-2021, diterima untuk diterbitkan :09-10-2021

\begin{abstract}
The Covid-19 pandemic resulted in new policies, one of which was to maintain physical distance.The application of maintaining physical distance has a huge impact in the world of education.This is due to the introduction of an online learning system. Teachers are the most affected.In desperate circumstances, teachers are required to transform faceto-face learning systems into online learning. Changes that occur suddenly affect the satisfaction of the teacher's life as a professional educator.No exception occurs in elementary school teachers. The difficulties experienced with the implementation of online learning systems cause discomfort.One way to reduce teacher discomfort is to practice gratitude.This study examined whether social support acted as a mediator of the influence of gratitude on the life satisfaction of elementary school teachers in South Tangerang.Life satisfaction measurements use the Satisfaction with Life Scale (SWLS) adaptation scale.Social support uses the Multidimentional Scale of Perceived Social Support (MSPSS) adaptation scale Zimmet (1988).The adaptation scale of the Gratitude Questionnaire-Six Item Form (GQ6) is used to measure gratitude.The results proved that social support mediated the influence of gratitude on life satisfaction in 125 elementary teachers in South Tangerang.The results support previous research in Korea (You et al., 2018), conducted on settings (COVID-19 pandemic) and different cultures.
\end{abstract}

Keywords: Life satisfaction, gratitude, social support, primary school teachers, online learning

\begin{abstract}
ABSTRAK
Pandemik Covid-19 menghasilkan kebijakan baru, salah satunya adalah menjaga jarak fisik. Penerapan menjaga jarak fisik sangat memiliki dampak dalam dunia pendidikan. Hal ini berimbas dengan diberlakukannya sistem pembelajaran daring. Guru merupakan pihak yang paling terkena dampak. Dalam keadaan terdesak, guru dituntut untuk mentransformasi sistem pembelajaran tatap muka menjadi pembelajaran daring. Perubahan yang terjadi secara tibatiba memengaruhi kepuasan hidup guru sebagai tenaga pendidik profesional. Tidak terkecuali terjadi pada guru Sekolah Dasar. Kesulitan yang dialami dengan pemberlakuan sistem pembelajaran daring mengakibatkan ketidaknyamanan. Salah satu cara yang dilakukan untuk mengurangi ketidaknyamanan guru adalah melatih rasa syukur. Penelitian ini menguji apakah dukungan sosial berperan sebagai mediator pengaruh rasa syukur terhadap kepuasan hidup guru SD di Tangerang Selatan. Pengukuran kepuasan hidup menggunakan skala adaptasi Satisfaction with Life Scale (SWLS). Dukungan sosial menggunakan skala adaptasi Multidimentional Scale of Perceived Social Support (MSPSS) Zimmet (1988). Skala adaptasi dari Gratitude Questionnaire-Six Item Form (GQ-6) digunakan untuk mengukur rasa syukur. Hasil penelitian membuktikan bahwa dukungan sosial memediasi pengaruh dari rasa syukur terhadap kepuasan hidup pada 125 guru SD di Tangerang Selatan. Hasil penelitian mendukung penelitian sebelumnya di Korea dilakukan pada setting (pandemik COVID-19) dan budaya berbeda.
\end{abstract}

Kata Kunci: Kepuasan hidup, rasa syukur, dukungan sosial, guru SD, pembelajaran daring

\section{PENDAHULUAN}

\section{Latar Belakang}

Mencapai kepuasan hidup merupakan harapan setiap individu. Diener (1984) menyatakan kepuasan hidup adalah penilaian secara global dari seseorang akan persepsi kognitif individu tentang kondisi kehidupan aktualnya saat ini dibandingkan dengan standar kehidupan idealnya. 
Penelitian-penelitian dalam bidang Psikologi yang telah dilakukan oleh peneliti terdahulu telah menunjukkan adanya kaitan yang kuat antara kepuasan hidup dengan kebahagiaan, perilaku, dan kinerja seseorang dalam pekerjaannya (Novanto \& Pali, 2019). Individu yang memiliki kepuasan hidup yang tinggi akan lebih berkomitmen pada pekerjaan dan organisasinya, serta menghasilkan kinerja dan produktivitas yang lebih baik bagi tempat kerjanya. Hal ini juga berdampak pada kesetiaan seseorang untuk bekerja pada satu organisasi dan mendedikasikan seluruh kemampuannya bagi organisasi tersebut (Erdogan et al., 2012). Sejalan dengan hal tersebut, Purnama (2014) menyatakan bahwa kepuasan hidup seseorang juga memengaruhi semangat hidup dan kemampuan seseorang untuk menyesuaikan diri pada berbagai perubahan, baik dalam dirinya sendiri maupun perubahan kondisi di lingkungan sekitarnya. Tidak hanya itu, kepuasan hidup juga memampukan seseorang untuk merasakan bahagia dalam situasi apapun (Linsiya, 2015).

Salah satu aspek penting dari kepuasan hidup manusia adalah kepuasan yang dirasakannya dalam aktivitas kerja. Umumnya, individu dengan status bekerja akan merasa lebih puas dalam hidupnya daripada individu yang tidak bekerja (Rojas, 2007). Kepuasan hidup memegang peranan penting dalam kualitas dan kinerja seseorang dalam profesi apapun, termasuk guru. Guru adalah pendidik profesional dengan tugas utama mendidik, mengajar, membimbing, mengarahkan, melatih, menilai, dan mengevaluasi peserta didik. (Novanto \& Pali, 2019). Profesi guru merupakan salah satu profesi penting bagi kemajuan masyarakat dan peradaban bangsa. Oleh karena itu, penting sekali bagi individu yang berprofesi sebagai seorang guru untuk merasakan kepuasan hidup yang tinggi sehingga mampu menjalankan tugas dan perannya secara optimal.

Dalam masa pandemik Coronavirus Disease (COVID-19) ini, banyak sekali terjadi transformasi pada media pembelajaran di Indonesia. Pandemi COVID-19 menyebabkan pemerintah untuk melahirkan kebijakan menjaga jarak fisik. Penerapan menjaga jarak fisik sangat memiliki dampak dalam dunia pendidikan. Kementerian Pendidikan dan Kebudayaan juga telah mengeluarkan kebijakan terhadap proses kegiatan belajar dan mengajar untuk dilakukan di rumah secara dalam jaringan.

Dampak yang dirasakan oleh guru terkait pelaksanaan pembelajaran daring yaitu tidak semua guru mahir menggunakan teknologi internet atau media sosial sebagai sarana pembelajaran, beberapa guru senior belum sepenuhnya mampu menggunakan perangkat atau fasilitas untuk penunjang kegiatan pembelajaran daring dan perlu pendampingan dan pelatihan terlebih dahulu. Kendala selanjutnya yaitu sebagian guru belum memiliki budaya belajar jarak jauh karena selama ini sistem belajar yang dilaksanakan adalah melalui tatap muka, para guru terbiasa berada di sekolah untuk berinteraksi dengan murid-murid, dengan adanya metode pembelajaran daring membuat para guru perlu waktu untuk beradaptasi dalam menghadapi perubahan baru yang secara tidak langsung akan memengaruhi kualitas hasil belajar (Purwanto et al., 2020).

Peneliti lalu melakukan komunikasi personal kepada dua orang guru Sekolah Dasar (SD) yang berinisial A dan B di salah satu Sekolah SD di Tangerang Selatan pada tanggal 15 Maret 2020. Berdasarkan hasil komunikasi personal, terdapat beberapa keluhan A terkait ketidakpuasan yang A rasakan dan dinilai kurang baik selama melakukan pembelajaran dari rumah melalui media daring. Adapun keluhan tersebut seperti waktu dan komunikasi yang sangat terbatas antara guru dengan siswa, adanya kendala yang dihadapi dalam menggunakan media pembelajaran saat proses pembelajaran daring sedang berlangsung, dibutuhkan waktu yang lebih banyak untuk mempersiapkan bahan pengajaran. Selain itu, A juga masih harus mengerjakan tugas administrasi sekolah yang perlu dikirimkan setiap harinya. Adapun dampak yang dirasakan bagi A dikarenakan beberapa hal di atas yaitu berkurangnya kepuasan yang dirasakan dalam membagikan ilmu serta 
kurangnya waktu istirahat yang dimiliki oleh A. Hal ini bertolak belakang dengan apa yang diharapkan A sebelumnya, yang mana ia berharap bisa membagi waktu antara mengajar dan waktu untuk keluarga. Dengan bekerja dari rumah, ia berharap dapat memiliki waktu lebih banyak dengan keluarga. Namun kenyataannya hal tersebut sulit untuk dilakukan. Komunikasi personal yang kedua dilakukan oleh peneliti dengan subjek seorang guru SD yang berinisial B. Dari hasil komunikasi personal tersebut menunjukkan bahwa B tidak begitu mengeluhkan ketidakpuasan yang dialaminya selama masa pandemi COVID-19, B merasa sangat puas dengan kehidupan yang B jalani sekarang. B menganggap tidak mengalami perubahan yang signifikan dengan diberlakukannya sistem pembelajaran daring. B mengaku telah melakukan persiapan yang matang sebelum pembelajaran berlangsung sehingga proses pembelajaran daring berjalan dengan lancar. B juga merasa memiliki lebih banyak waktu dengan keluarga. Hal ini dikarenakan menurut pengakuan B, ia selalu membawa santai akan setiap hal yang terjadi dalam hidupnya juga tidak lupa ia menerapkan kebiasaan bersyukur.

Kepuasan hidup menjadi salah satu dimensi yang diukur untuk mengukur kebahagiaan seseorang (Badan Pusat Statistik, 2017). Penelitian yang dilakukan oleh Ferrer (2017) mendapatkan hasil bahwa rasa syukur secara signifikan memprediksi kepuasan hidup pada kesejahteraan psikologis dan fisik pada 309 mahasiswa di Spanyol. Penelitian serupa yang dilakukan oleh (Robustellt \& Whisman, 2018) pada 945 orang dewasa paruh baya dan dewasa yang lebih tua di United States dan Jepang menunjukkan bahwa individu yang memiliki rasa syukur yang tinggi juga memiliki kepuasan hidup yang tinggi. Didukung dengan hasil penelitian (Sucitra et al., 2019) menunjukkan bahwa aktivitas gratitude journal dapat digunakan sebagai salah satu jenis intervensi yang dapat mengurangi gejala depresif pada 6 penderita kanker. Penelitian lain yang dilakukan oleh (You et al., 2018) pada 877 siswa remaja di Korea menunjukkan bahwa siswa yang bersyukur dengan dukungan sosial sebagai mediator mengalami kesulitan emosional yang lebih rendah sehingga menghasilkan peningkatan kepuasan hidup.

Berbeda hal dengan penelitian sebelumnya, penelitian ini dilakukan pada setting dan budaya yang berbeda. Selain itu, penelitian juga dilakukan pada masa pandemik COVID-19 di mana terjadi perubahan pola hidup yang saat ini dialami oleh seluruh penduduk dunia yang belum pernah terjadi sebelumnya. Dengan berbasis pada semua pengalaman dalam penelitian terdahulu serta fenomena pembelajaran daring yang saat ini terjadi pada masa pandemik COVID-19, penelitian ini diharapkan dapat menghasilkan temuan lebih lanjut mengenai pengaruh dari rasa syukur terhadap kepuasan hidup dengan dukungan sosial sebagai mediator pada guru SD di Tangerang Selatan pada saat pelaksanaan pembelajaran daring.

\section{Rumusan Masalah}

Penggunaan variabel mediator digunakan untuk mengetahui pengaruh baik secara langsung atau tidak langsung terhadap variabel tergantung. Berdasarkan latar belakang masalah, maka rumusan permasalahan pada penelitian ini adalah apakah dukungan sosial memediasi pengaruh rasa syukur terhadap kepuasan hidup pada guru SD saat pembelajaran daring?

\section{METODE PENELITIAN}

\section{Partisipan penelitian}

Partisipan dalam penelitian ini adalah guru Sekolah Dasar kelas 1 hingga kelas 6. Adapun kriteria partisipan adalah: (a) guru SD kelas 1 sampai dengan kelas 6; (b) pernah melakukan kegiatan sistem pembelajaran jarak jauh berbasis daring; (c) mengajar di wilayah Tangerang Selatan. Tidak terdapat batasan usia, jenis kelamin, agama, suku, agama, maupun ras dalam penelitian ini. Jumlah partisipan dalam penelitian ini berjumlah 125 orang. 
Penelitian ini menggunakan metode kuantitatif non eksperimen. Teknik pengambilan sampel penelitian dilakukan menggunakan teknik purposive sampling. Adapun kriteria partisipan adalah: (a) guru SD kelas 1 sampai dengan kelas 6; (b) pernah melakukan kegiatan sistem pembelajaran jarak jauh berbasis daring; (c) mengajar di wilayah Tangerang Selatan. Tidak terdapat batasan usia, jenis kelamin, agama, suku, agama, maupun ras dalam penelitian ini.

\section{Instrumen Penelitian}

Metode pengumpulan data dalam penelitian ini menggunakan: (a) pengukuran variabel kepuasan hidup melalui adaptasi alat ukur Satisfaction with Life Scale (SWLS) disusun oleh Diener et al. (1985) yang terdiri 5 pernyataan. Skala ini adalah alat ukur yang paling banyak digunakan untuk mengukur kepuasan hidup seseorang secara global (Novanto \& Pali, 2019). Pengukuran kepuasan hidup menggunakan SWLS yang bersifat unidimensional, yaitu berdimensi tunggal dengan nilai alpha cronbach sebesar 0.854. Pengukuran kepuasan hidup menggunakan skala Likert-7 berbentuk kuesioner. Kuesioner ini menggunakan tujuh alternatif pilihan jawaban yaitu sangat tidak setuju (STS) dengan bobot skor 1, tidak setuju (TS) dengan bobot skor 2, sedikit tidak setuju (STS) dengan bobot skor 3, netral (N) dengan bobot skor 4, sedikit setuju (SS) dengan bobot skor 5, setuju (S) dengan bobot skor 6, dan sangat setuju (SS) dengan bobot skor 7; (b) pengukuran dukungan sosial menggunakan skala adaptasi Multidimentional Scale of Perceived Social Support (MSPSS) oleh Zimmet (1988) menggunakan skala Likert-7 berupa kuesioner yang terdiri dari 12 butir pernyataan. Alat ukur MSPSS mengukur tiga aspek dukungan sosial yang bersumber dari keluarga, teman dan orang yang dianggap istimewa di dalam kehidupan (Nugraheni et al., 2019). Kuesioner ini menggunakan tujuh alternatif pilihan jawaban yaitu sangat tidak setuju sekali (STSS) dengan bobot skor 1, sangat tidak setuju (STS) dengan bobot skor 2, agak tidak setuju (ATS) dengan bobot skor 3, netral (N) dengan bobot skor 4, agak setuju (AS) dengan bobot skor 5, sangat setuju (SS) dengan bobot skor 6, dan sangat setuju sekali (SSS) dengan bobot skor 7 . Nilai alpha cronbach pada masing-masing dimensi adalah sebesar 0.884 pada dimensi keluarga, sebesar 0,826 pada dimensi teman, dan sebesar 0.868 pada dimensi orang istimewa. (c) Pengukuran variabel rasa syukur menggunakan adaptasi instrumen The Gratitude QuestionnaireSix Item Form (GQ-6) oleh McCullough et al. (2002) yang terdiri dari 6 butir pernyataan serta terdiri dari dimensi intensity, frequency, span dan density (Sucitra et al., 2019). Pengukuran rasa syukur menggunakan skala Likert-7 berbentuk kuesioner dengan nilai alpha cronbach sebesar 0.757. Kuesioner ini menggunakan tujuh alternatif pilihan jawaban yaitu sangat tidak setuju (STS) dengan bobot skor 1, tidak setuju (TS) dengan bobot skor 2, sedikit tidak setuju (STS) dengan bobot skor 3, netral (N) dengan bobot skor 4, sedikit setuju (SS) dengan bobot skor 5, setuju (S) dengan bobot skor 6, dan sangat setuju (SS) dengan bobot skor 7. Total dari keseluruhan alat ukur berjumlah 23 butir pernyataan.

Peneliti melakukan validitas dan reliabilitas alat ukur pada masing-masing variabel. Pengujian hipotesis penelitian dilakukan dengan uji regresi linier. Di dalam uji regresi linear berganda dimulai dengan uji asumsi klasik sebagai syarat uji regresi linear berganda. Peneliti melakukan uji asumsi klasik terlebih dahulu dengan melakukan uji normalitas. Uji normalitas yang dilakukan pada penelitian ini adalah uji Kolmogorov-Smirnov (K-S). Uji normalitas dilakukan untuk melihat nilai residual terdistribusi normal atau tidak.

\section{HASIL DAN PEMBAHASAN Data Demografi Partisipan}

Total jumlah partisipan dalam penelitian ini berjumlah 125 orang. Adapun data demografis partisipan penelitian berdasarkan jenis kelamin dapat dilihat pada tabel 1. 


\section{Tabel 1}

Gambaran Umum Partisipan Berdasarkan Jenis Kelamin

\begin{tabular}{ccc}
\hline Jenis kelamin & Frekuensi & Persentase (\%) \\
\hline Perempuan & 92 Orang & 73,60 \\
Laki-laki & 33 Orang & 26,40 \\
Total & 125 Orang & 100,00 \\
\hline
\end{tabular}

Partisipan penelitian pada penelitian ini memiliki rentang usia yang bervariasi dimulai dari usia 21 tahun hingga lebih dari usia 50 tahun. Gambaran partisipan penelitian ditinjau dari rentang usia dapat dilihat pada tabel 2 .

\section{Tabel 2}

Gambaran Umum Partisipan Berdasarkan Usia

\begin{tabular}{ccc}
\hline Rentang Usia (tahun) & Frekuensi & Persentase (\%) \\
\hline $21-25$ & 21 & 16.8 \\
$26-30$ & 30 & 24.0 \\
$31-35$ & 28 & 22.4 \\
$36-40$ & 21 & 16.8 \\
$41-45$ & 15 & 12.0 \\
$46-50$ & 6 & 4.8 \\
$>50$ & 4 & 3.2 \\
\hline Total & 125 & 100.0
\end{tabular}

Berdasarkan data pada tabel 2 dapat dilihat bahwa partisipan dalam penelitian ini didominasi oleh partisipan yang berada pada rentang usia usia 26 hingga 30 tahun sebanyak 30 orang (24\%). Adapun rentang usia yang paling sedikit pada penelitian ini berada pada rentang usia $>50$ tahun yaitu berjumlah 4 orang $(3.2 \%)$.

Peneliti mengkategorikan status marital partisipan penelitian ke dalam tiga kategori status marital. Gambaran partisipan penelitian ditinjau dari status marital dapat dilihat pada tabel 3.

\section{Tabel 3}

Gambaran Partisipan Berdasarkan Status Marital

\begin{tabular}{ccc}
\hline Status perkawinan & Frekuensi & Persentase (\%) \\
\hline Belum Menikah & 50 & 40.0 \\
Menikah & 73 & 58.4 \\
Cerai & 2 & 1.6 \\
Total & 125 & 100.0 \\
\hline
\end{tabular}

Berdasarkan data pada tabel 3.3 dapat dilihat bahwa partisipan penelitian ini memiliki status marital yang bervariasi. Partisipan yang belum menikah berjumlah 50 orang (40.0\%), 73 orang sudah menikah $(58.4 \%)$, dan 2 orang $(1,6 \%)$ yang memiliki status marital cerai. Dengan demikian, partisipan penelitian dalam penelitian ini didominasi oleh partisipan dengan status marital yang telah menikah.

Peneliti melakukan uji hipotesis penelitian dengan menggunakan uji regresi linier dengan menggunakan bantuan IBM SPSS versi 22 for windows. Uji regresi linear berganda dimulai dengan uji asumsi klasik sebagai syarat uji regresi linear berganda. Peneliti melakukan uji asumsi 
klasik terlebih dahulu dengan melakukan uji normalitas. Uji normalitas yang dilakukan pada penelitian ini yaitu uji Kolmogorov-Smirnov (K-S). Uji normalitas dilakukan untuk melihat nilai residual terdistribusi normal atau tidak. Pada uji K-S, data dapat dikatakan berdistribusi normal jika memiliki nilai signifikansi $>0.05$. Uji asumsi klasik pada penelitian ini dapat dilihat pada tabel 4.

\section{Tabel 4}

Uji Normalitas

\begin{tabular}{cc}
\hline Kolmogorov-Smirnov Test & Nilai \\
\hline Df & 125 \\
Asymp. Sig. (2-tailed) & 0,296 \\
\hline
\end{tabular}

Berdasarkan data pada tabel 4, diperoleh uji Kolmogorov-Smirnov (K-S) dengan nilai signifikansi 0.296 atau lebih besar (>0.05). Hal ini menunjukkan bahwa data terdistribusi normal. Dengan demikian, asumsi atau persyaratan normalitas dalam model regresi sudah terpenuhi.

Menurut Baron dan Kenny (1986) dalam menguji mediasi, terdapat tiga persamaan regresi yang perlu dilakukan, yaitu (1) regresi variabel independen terhadap variabel mediator, (2) variabel independen terhadap variabel dependen, dan (3) variabel independen dan variabel mediator terhadap variabel dependen. Pada penelitian ini uji regresi dilakukan sebanyak tiga kali. Pertama, uji regresi bertujuan untuk melihat pengaruh dari variabel rasa syukur terhadap variabel kepuasan hidup. Analisis regresi linear akan dibahas per bagian secara mendalam.

\section{Tabel 5}

\section{Output SPSS Model Summary Regresi Linear Sederhana Pertama}

\begin{tabular}{|c|c|c|c|}
\hline $\mathbf{R}$ & R Square & Adjusted R Square & $\begin{array}{l}\text { Std. Error of the } \\
\text { Estimate }\end{array}$ \\
\hline $.320^{\mathrm{a}}$ & 0,102 & 0,095 & 8,93 \\
\hline
\end{tabular}

Berdasarkan data pada tabel 6 perolehan R square sebesar 0,102 atau 10.2\%. Hal ini berarti, rasa syukur memberikan pengaruh terhadap kepuasan hidup sebesar 10,2\% sedangkan 89,8\% dipengaruhi oleh variabel lain. Nilai koefisien regresi sebesar 0,32 dengan signifikan sebesar 0,000 $(\mathrm{p}<0,05)$. Dengan demikian dinyatakan bahwa rasa syukur memiliki pengaruh yang signifikan terhadap kepuasan hidup. Koefisien regresi memiliki arah yang positif sehingga semakin tinggi rasa syukur yang dimiliki seseorang, maka akan berdampak semakin tinggi juga pada kepuasan hidup seseorang. Selanjutnya peneliti melakukan uji regresi kedua yang bertujuan untuk melihat pengaruh dari variabel rasa syukur terhadap variabel dukungan sosial Hasil output statistik deskriptif regresi linear sederhana variabel rasa syukur terhadap variabel dukungan sosial dapat diamati pada tabel 6 .

\section{Tabel 6}

Output SPSS Model Summary Regresi Linear Sederhana Kedua

\begin{tabular}{|c|c|c|c|}
\hline $\mathbf{R}$ & R Square & Adjusted R Square & $\begin{array}{c}\text { Std. Error of the } \\
\text { Estimate }\end{array}$ \\
\hline $.542^{\mathrm{a}}$ & 0,294 & 0,288 & 8,13 \\
\hline
\end{tabular}


Berdasarkan data pada tabel 6 perolehan R square sebesar 0,294 atau 29.4\%. Hal ini berarti, rasa syukur memberikan pengaruh terhadap dukungan sosial sebesar 29,4\% sedangkan 70,8\% dipengaruhi oleh variabel lain. Nilai koefisien regresi sebesar 0,54 dengan signifikan sebesar 0,000 $(\mathrm{p}<0,05)$. Dengan demikian dinyatakan bahwa rasa syukur memiliki pengaruh yang signifikan terhadap dukungan sosial. Koefisien regresi memiliki arah yang positif sehingga semakin tinggi rasa syukur yang dimiliki oleh seseorang maka akan semakin tinggi juga dukungan sosial yang diterima oleh seseorang dari lingkungannya. Selanjutnya peneliti melakukan uji regresi ketiga yang bertujuan untuk melihat pengaruh dari variabel rasa syukur terhadap variabel kepuasan hidup dengan dukungan sosial sebagai variabel mediator. Hasil output statistik deskriptif regresi variabel rasa syukur terhadap variabel kepuasan hidup dengan dukungan sosial sebagai variabel mediator dapat diamati pada tabel 7.

\section{Tabel 7}

Output SPSS Model Summary Regresi Variabel Mediasi

\begin{tabular}{|c|c|c|c|}
\hline $\mathbf{R}$ & R Square & Adjusted R Square & $\begin{array}{l}\text { Std. Error of the } \\
\text { Estimate }\end{array}$ \\
\hline $.531^{\mathrm{a}}$ & 0,282 & 0,270 & 8,021 \\
\hline
\end{tabular}

Berdasarkan data pada tabel 7 perolehan R square sebesar 0,282 atau 28.2\%. Hal ini berarti, ada pengaruh dari rasa syukur terhadap kepuasan hidup yang dimediasi oleh dukungan sosial sebesar $28,2 \%$ sedangkan $71,8 \%$ dipengaruhi oleh variabel lain. Dengan demikian, hipotesis pada penelitian ini telah terjawab bahwa dukungan sosial memediasi pengaruh dari rasa syukur terhadap kepuasan hidup pada guru SD di Tangerang Selatan saat pembelajaran daring.

Nilai koefisien regresi sebesar 0,046 dengan signifikan sebesar 0,616 ( $p>0,05)$ pada variabel rasa syukur terhadap kepuasan hidup. Dengan demikian dinyatakan bahwa pengaruh yang signifikan dari rasa syukur terhadap kepuasan hidup ditolak. Artinya, rasa syukur tidak memiliki pengaruh yang signifikan terhadap kepuasan hidup. Sedangkan pada variabel dukungan sosial diperoleh nilai koefisien regresi sebesar 0,492 dengan signifikan sebesar 0,000 ( $\mathrm{p}<0,05)$. Dengan demikian, dinyatakan pengaruh yang signifikan dari dukungan sosial terhadap kepuasan hidup diterima. Artinya, dukungan sosial memiliki pengaruh yang signifikan terhadap kepuasan hidup.

\section{KESIMPULAN DAN SARAN}

\section{Kesimpulan}

Berdasarkan hasil penelitian didapatkan hasil bahwa dukungan sosial terbukti memberikan pengaruh sebagai mediator dari rasa syukur terhadap kepuasan hidup pada guru SD di wilayah Tangerang Selatan saat penerapan pembelajaran daring. Adapun kontribusi yang diberikan yaitu sebesar $28,2 \%$ sedangkan $71,8 \%$ dipengaruhi oleh variabel lain. Sementara sebelum terdapat variabel mediator kontribusi yang diberikan oleh variabel rasa syukur sebesar 10,2\% sedangkan sebesar $89,8 \%$ dipengaruhi variabel lain.

Hal ini membuktikan bahwa dukungan sosial yang diterima oleh seseorang dari lingkungan di sekitarnya menjadi mediator dari rasa syukur terhadap kepuasan hidup seseorang. Namun hal tersebut tidaklah menjadi satu-satunya faktor yang memengaruhi kepuasan hidup seseorang. Hal tersebut terbukti dengan ditemukannya tingkat kepuasan hidup yang bervariasi mulai dari kategori rendah, sedang hingga tinggi pada guru SD di wilayah Tangerang Selatan. Selain dari rasa syukur yang dimediasi oleh dukungan sosial terdapat faktor lain yang juga dapat mempengaruhi kepuasan hidup seseorang. 


\section{Saran}

Bagi peneliti selanjutnya, disarankan untuk meningkatkan lamanya frekuensi pada saat pengambilan data di lapangan agar dapat memenuhi jumlah sampel yang mewakili jumlah populasi yang ada. Penelitian ini menggunakan teknik purposive sampling yang kemudian untuk menetapkan jumlah sampel yang ada menggunakan rumus Slovin dimana dihitung jumlah sampel yang dibutuhkan berdasarkan jumlah populasi yang ada pada suatu wilayah. Dengan demikian, untuk peneliti selanjutnya disarankan menetapkan pemilihan waktu serta menentukan lamanya frekuensi yang tepat guna mendapatkan jumlah sampel yang sesuai dengan yang dibutuhkan. Adapun hal lain yang perlu dikaji lebih lanjut berdasarkan hasil penelitian ini adalah variabelvariabel lain yang mempengaruhi kepuasan hidup seseorang. Di dalam penelitian ini hanya terdapat variabel rasa syukur dan dukungan sosial, peneliti selanjutnya perlu mengkaji lebih lanjut dengan menambahkan variabel-variabel lain serta melakukan wawancara yang lebih mendalam kepada partisipan penelitian dengan menggunakan pendekatan mixed-method guna memperoleh hasil penelitian yang lebih mendalam. Berdasarkan komunikasi personal dengan tiga orang partisipan dalam penelitian ini, peneliti menemukan keberhargaan diri menjadi salah satu variabel yang dianggap dapat mempengaruhi kepuasan hidup seseorang. Peneliti selanjutnya, dapat juga melibatkan variabel keberhargaan diri, ataupun melibatkan variabel psikologi positif lainnya seperti harapan atau optimisme dalam memprediksi kepuasan hidup seseorang. Hasil penelitian ini dapat dijadikan acuan bagi pihak-pihak yang bekerja dalam dunia pendidikan bahwa aktivitas yang sederhana seperti kebiasaan bersyukur dan memberikan dukungan sosial memiliki potensi untuk membentuk emosi positif pada individu yang akan berimbas pada kepuasan hidup individu.

Adapun saran praktis yang dapat dilakukan masyarakat umum maupun para guru untuk meningkatkan rasa syukur dapat dilakukan dengan cara membiasakan diri menuliskan gratitude journal secara rutin dan saling bertukar pengalaman menceritakan hal-hal yang disyukuri setiap hari kepada orang-orang terdekat. Sementara hal-hal yang dapat dilakukan dalam memberikan dukungan sosial kepada sesama guna meningkatkan kepuasan hidup dapat dilakukan dengan beberapa cara antara lain: menawarkan bantuan kepada sesama yang membutuhkan bantuan, menjadi pendengar yang baik bagi sesama, membuat kelompok diskusi sebagai wadah untuk bertukar informasi dan memberikan dukungan.

\section{Ucapan Terima Kasih (Acknowledgement)}

Peneliti mengucapkan terima kasih yang sebesar-besarnya kepada pihak-pihak yang telah berkontribusi besar dalam penyelesaian dan penulisan studi ini, khususnya kepada partisipan penelitian di berbagai sekolah yang berada di di wilayah Tangerang Selatan.

\section{REFERENSI}

Baron, R. M., \& Kenny, D. A. (1986). The moderator-mediator variable distinction in social psychological research: Conceptual, strategic, and statistical considerations. Journal of personality and social psychology,51(6), 1173. https://doi.org/10.1037/00223514.51.6.1173

BPS/ES, H. (2017, Agustus 15). Sekretariat kabinet Republik Indonesia. https://setkab.go.id

Diener, E. (1984). Subjective well-being. Psychological Bulletin, 95(3), 542. https://doi.org/10.1037/0033-2909.95.3.542

Diener, E. D., Emmons, R. A., Larsen, R. J., \& Griffin, S. (1985). The satisfaction with life scale. $\begin{array}{lllll}\text { Journal of Personality } & \text { Assessment, } & 49(1), & 71-75 .\end{array}$ https://doi.org/10.1207/s15327752jpa4901_13 
Erdogan, B., Bauer, T. N., Truxillo, D. M., \& Mansfield, L. R. (2012). Whistle while you work: A review of the life satisfaction literature. Journal of Management, 38(4), 103-108. https://doi.org/10.1177/0149206311429379

Ferrer, C. S. (2017). The relationship between Gratitude and Life Satisfaction in a sample of Spanish university students: The moderation role of gender. Anales De Psicología, 33(1), 114-119. https://doi.org/10.6018/analesps.33.1.226671

Linsiya, R.W. (2015). Perbedaan kepuasan hidup antara mahasiswa strata 1 (S1) dan strata 2 (S2). Prosiding Seminar Nasional Psikologi dan Kemanusiaan, Psychology Forum UMM, ISBN: 978-979-796-324-8.

Nugraheni, A. P. W., Tiatri, S., \& Mularsih, H. (2019). Peran efikasi diri dan dukungan sosial terhadap regulasi diri belajar pada warga belajar kejar paket C. Jurnal Muara Ilmu Sosial, Humaniora, dan Seni, 2(2), 700-709. http://dx.doi.org/10.24912/jmishumsen.v2i2.2867

Pali, M., \& Novanto, Y. (2019). Teacher's life satisfaction in Palopo and Toraja: An analysis study based on demographic factors. Jurnal Sains Psikologi, 8(2), 207-217. http://dx.doi.org/10.17977/um023v8i22019p207

Purnama, D. (2014, November). Manusia: Subyek yang mencari makna hidup melalui karya. Info Psikiater.

http://infopsikiater.blogspot.co.id/2014/11/manusia_subjek_yang_mencari_makna_hidup. html

Purwanto, A., Asbari, M., Pramono, R., \& Santoso, P. B. (2020). Studi eksploratif dampak pandemi Covid-19 terhadap proses pembelajaran online di Sekolah Dasar. Journal of Education, Psychology and Counseling, 2(1), 2716-4446. https://ummaspul.ejournal.id/Edupsycouns/article/view/397

Robustelli, B. L., \& Whisman, M. A. (2018). Gratitude and life satisfaction in the United States and Japan. Journal of happiness studies, 19(1), 41-55. https://doi.org/10.1007/s10902-0169802-5

Rojas, M. (2007) The complexity of well-being: A life satisfaction conception and a domains-oflife approach. In Gough, I. and McGregor, A. (Eds.), Wellbeing in developing countries: From theory to research (pp. 242-258). Cambridge University Press.

Santoso, S. (2018). Panduan lengkap IBM SPSS versi 25. PT Elex Media Komputindo.

Sucitra, E., Ma'at, S., \& Tiatri, S. (2019). Penerapan gratitude journal untuk menurunkan gejala depresif pada penderita kanker: Studi dengan ecological momentary assessment. Journal Muara Ilmu Sosial. Humaniora, Dan Seni, 3(1), 123. https://doi.org/10.24912/jmishumsen.v3i1.3466

Sugiyono. (2012). Metode penelitian kuantitatif dan kualitatif. $R \& D$. Alfabeta.

Sugiyono. (2018). Metode penelitian kuantitatif, kualitatif, dan R\&D. Alfabeta.

You, S., Lee, J., Lee, Y., \& Kim, E. (2018). Gratitude and life satisfaction in early adolescence: The mediating role of social support and emotional difficulties. Personality and Individual Differences, 130(2018), 122-128. https://doi.org/10.1016/j.paid.2018.04.005

Zimet, G. D., Dahlem, N. W., Zimet, S. G., \& Farley, G. K. (1988). The multidimensional scale of perceived social support. Journal of Personality Assessment, 52(1), 30-41. https://doi.org/10.1207/s15327752jpa5201_2 